\title{
METAFORA DALAM NASKAH DRAMA “SENJA DENGAN DUA KELELAWAR" KARYA KIRDJOMULYO
}

\author{
Alfia Nurul Hidayah ${ }^{1}$, Wahyu Oktavia ${ }^{2}$ \\ Tadris Bahasa Indonesia, Institut Agama Islam Negeri Surakarta \\ Posel:alfia4637@gmail.com¹; oktaviawahyu17@gmail.com²
}

\begin{abstract}
This study aims to describe the type of metaphor in the drama script Senja dengan Dua Kelelawar. This study uses a type of qualitative descriptive research where unbound places analyze the form of descriptions that are not in the form of numbers or coefficients about the relationship of variables. The method used is content analysis by examining the contents of a document. In this study the document in question is a drama script Senja dengan Dua kelelawar. The data collection technique used in this research is the observation and note technique, because the data is in the form of text. The data analysis technique uses data reduction, data presentation and verification. Based on data analysis carried out on the drama Senja dengan Dua Kelelawar by Kirdjomulyo, it contains four types of metaphoric language styles according to the Parera theory consisting of 9 data anthropomorphic metaphors, 3 animal metaphor data, 7 data abstract to concrete metaphors, and 4 data synesthesia metaphors.
\end{abstract}

Keywords: semantics; metaphor; drama script.

\begin{abstract}
Abstrak
Penelitian ini bertujuan untuk mendeskripsikan jenis metafora dalam naskah drama Senja dengan Dua kelelawar karya Kirdjomulyo. Penelitian ini menggunakan jenis penelitian deskriptif kualitatif dimana tempat tidak terikat yang menganalisis bentuk deskripsi yang tidak berupa angka atau koefisien tentang hubungan variabel. Metode yang digunakan adalah analisis isi dengan menelaah isi dari suatu dokumen. Dalam penelitian ini dokumen yang dimaksud adalah naskah drama Senja dengan Dua kelelawar. Teknik pengumpulan data yang digunakan dalam penelitiaan ini adalah teknik observasi dan catat, karena data-datanya berupa teks. Teknik analisis data menggunakan reduksi data, penyajian data dan verivication. Berdasarkan analisis data yang dilakukan terhadap naskah drama Senja dengan Dua Kelelawar karya Kirdjomulyo mengandung empat jenis gaya bahasa metafora menurut teori Parera yang terdiri dari metafora antropomorfik 9 data, metafora hewan 3 data, metafora abstrak ke konkret 7 data, dan metafora sinestesia 4 data.
\end{abstract}

Kata Kunci: semantic; metafora; naskah drama.

\section{PENDAHULUAN}

Kajian makna dalam bahasa tercakup dalam salah satu bidang linguistik, yakni semantik. Verhaar (dalam Pateda. 2001: 7) memberikan batasan semantik sebagai teori makna atau teori arti. Metafora dalam linguistik disorot melalui pendekatan semantik karena pembicaraan mengenai metafora sebaga salah satu gaya bahasa yang diakibatkan oleh perubahan makna mau tidak mau selalu berkaitan dengan makna dan seluk beluknya, dan kesemuanya itu berada di bawah payung salah satu bidang linguistik yaitu semantik.

Semantik adalah salah satu cabang linguistik yang mengkaji bahasa. Studi semantik membahas tentang arti bahasa atau makna bahasa. Dalam linguistik, metafora termasuk dalam bidang semantik. Penerapan makna dalam metafora berbeda dengan penerapan makna pada kata kata bermakna refensial. Pada kata yang ferensial, makna merupakan hasil abstraksi ciri-ciri hakiki dan referensi yang ditunjuk tetapi pada metafora, referensi dari sebuah kata kadang-kadang menyimpang dengan makna yang bersangkutan. (Verhaar, 2008: 389) 
Di dalam semantik terdapat bentuk-bentuk gaya bahasa seperti idiom, kiasan ketaksaan, eufimisme, dan metafora. Salah satu bentuk gaya bahasa yang sering dikenal yaitu metafora. Metafora banyak digunakan dalam pengkajian karya sastra dalam baik dalam jenis puisi, novel ataupun naskah drama. Metafora memakai kata-kata yang bukan dalam makna sebenarnya. Secara tradisional metafora dipandang sebagai bentuk terpenting dari penggunaan bahasa figuratife, dan biasanya dianggap mencapai bentuk yang sempura pada bahasa sastra atau bahas puisi (Saeed dalam Giyoto, 2013: 69). Struktur dasar metafora sangat sederhana, yaitu sesuatu yang dibicarakan, dan ada sesuatu yang dipakai sebagai perbandingan. Itu sebabnya Badudu (dalam Pateda: 234) mengatakan bahwa gaya bahasa metafora adalah gaya bahasa yang memperbandingkan suatu benda dengan yang lain, sedangkan Chaer (dalam pateda: 235) mengatakan, metafora dilihat dari segi digunakannya sesuatu untuk memperbandingkan yang lain dengan yang lain.

Di antara sekian banyak metafora yang diekspresikan manusia Parera (2004: 119) membagi jenis metafora menjadi empat. Pertama, metafora bercitra antropomorfik merupakabn suatu gejala semesta. Para pemakai bahasa ingin membandingkan kemiripan pengalaman dengan apa yang terdapat pada dirinya atau tubuh mereka sendiri. Kedua, metafora bercitra hewan atau metafora hewani yang menjadi kebiasaan para pemakai bahasa untuk menggambarkan satu kondisi atau kenyataan di alam pengalaman pemakai bahasa. Metafora dengan unsur binatang cenderung dikenakan pula tanaman. Ketiga, metafora bercitra abstrak ke konkret yang merupakan salah satu kecenderungan utama dalam metafora ialah mengalihkan ungkapam-ungkapan yang abstrak ke ungkapan yang lebih konkret, sering pengalihan ungkapan itu masih bersifat transparan, tetapi dalam beberapa kasus penelusuran etimologi perlu dipertimbangkan untuk memahami metafora tertentu. Keempat, metafora bercitra sinestesia yang merupakan salah satu tipe metafora berdasarkan pengalihan indra, pengalihan dari satu indra ke indra yang lain. Dalam bahasa sehai-hari orang sering mendengar ungkapan "enak didengar" untuk musik, walaupun makna enak selalu dikaitkan dengan indra rasa, "sedap dipandang mata" merupakan pengalihan dari indra rasa ke indra penglihatan.

Drama merupakan salah satu jenis karya sastra yang diperankan oleh manusia di panggung yang di setting sesuai dengan jalan cerita. Drama dapat dikategorikan sebagai seni pertunjukan, karena dipentaskan dan dipertontonkan. Drama dituliskan dalam bentuk naskah yang dikarang oleh penulis. Dalam sebuah naskah drama terdapat makna-makna kata perumpaan yang menjadikan naskah tersebut memiliki seni sastra yang tinggi (Suprabowo dan Gunawan, 2018). Drama merupakan tiruan kehidupan manusia yang diperantas, ketika melihat drama penonton seolah menyaksikan gambaran kehidupa dalam masyarakat konflik yang disajikan dalam drama berasa dari konflik batin. Drama dapat diartikan pula sebagai potret kehidupan manusia, gamaran suka duka, dan hitam putih kehidupan. (Widyahening, 2014: 1).

Jenis-jenis drama disadarkan pada jenis sterotip manusia dan tanggapan manusia terhadap hidup dan kehidupan pada abad XVIII ada jenis naskah drama, diantaranya lelucon, banyolan, opera balada, komedi sentimental, komedi tingkat tinggi, tragedy burjois, dan tragedy neoklasih. Selanjutnya jenis drama diklasifikasikan menjadi 4 jenis yaitu Tragedi (duka cita), Komedi (drama riang), Melodrama (drama melodius) dan dagelan (farce). Suatu 
drama terdapat berbagai bentuk dan fungsi gaya bahasa. Gaya bahasa adalah penggunaan dari bahasa seseorang dalam bertutur dan menulis. Cara ini digunakan seorang pengarang untuk menuturkan imajinasinya. Seorang pengarang menggunakan gaya bahasa berharap pesan yang hendak dikirimkan akan sampai dan memberi pengaruh juga kesan kepada pembaca (Brata, 2018).

Penelitian ini membahas tentang gaya bahasa dalam naskah drama, gaya bahasa yang dikaji ialah gaya bahasa metafora dalam naskah drama Senja dengan Dua kelelawar karya Kirdjomulyo. Metafora adalah semacam analogi yang membadingkan dua hal secara langsung. Dalam penelitian ini pengarang membandingkan metafora.

Berkaitan dengan uraian di dalam latar belakang, rumusan masalah dalam penelitian ini adalah bagaimana jenis metafora dalam naskah drama Senja dengan Dua kelelawar karya Kirdjomulyo. Penelitian ini bertujuan menganalisis jenis metafora dalam naskah drama Senja ddengan Dua kelelawar karya Kirdjomulyo.

Secara teoretis, penelitian ini diharapkan dapat bermanfaat untuk memberikan pengetahuan yang berhubungan dengan metafora, khususnya mengenai wujud tuturan metaforis dalam naskah drama Senja dengan dua kelelelawar. Selain itu juga memberikan kontribusi perkembangan pengetahuan di bidang linguistik semantik, khususnya metafora. Sementara itu, manfaat praktis dari penelitian ini adalah menambah perbendaharaan penelitian bidang metafora, agar memberikan referensi tambahan bagi penelitian metafora selanjutnya.

Penelitian yang relevan dengan penelitian ini ialah Arnis Anawati (2015) dalam skripsinya membahas mengenai "Analisis Penyimpangan Prinsip Kerja Sama dalam Naskah Drama Senja dengan Dua kelelawar karya Kirdjomulyo. Penelitian ini membahas tentang penyimpangan prinsip kerja sama dan tujuan penyimpangan kerja sama. Hasil Penelitian menunjukkan bahwa (1) penyimpangan prinsip kerja sama dengan frekuensi dan persentase meliputi maksim kuantitas sebanyak 11 kali (47,83\%), maksim relevansi sebanyak 6 kali (26,09\%), maksim pelaksanaan sebanyak 4 kali (17,39\%), serta maksim kualitas sebanyak 2 kali $(8,69 \%)$ dan (2) tujuan penyimpangan prinsip kerja sama dengan frekuensi dan persentase meliputi maksim kuantitas bertujuan direktif berupa meminta konfirmasi sebanyak 3 kali (12\%), dan menyampaikan saran sebanyak 2 kali (8\%), tujuan penyimpangan ekspresif berupa menyampaikan basa-basi dan memohon maaf serta tujuan penyimpangan representatif berupa memberikan informasi sebanyak 2 kali (8\%), mencurahkan isi hati sebanyak 1 kali (4\%), dan mengungkapkan rasa kesal sebanyak 1 kali (4\%). Maksim kualitas bertujuan penyimpangan direktif berupa menyampaikan saran dan meminta konfirmasi sebanyak 1 kali (4\%), maksim relevansi bertujuan penyimpangan direktif berupa meminta informasi sebanyak 3 kali (12\%), menyampaikan saran, menyindir, meminta konfirmasi sebanyak 1 kali (4\%), maksim pelaksanaan bertujuan penyimpangan direktif berupa menyampaikan saran sebanyak 2 kali (8\%), tujuan penyimpangan ekspresif berupa menyampaikan basa-basi sebanyak 1 kali (4\%), tujuan penyimpangan representatif berupa mencurahkan isi hati, memberikan informasi, mengungkapkan rasa kesal sebanyak 1 kali (4\%).

Persamaan dan perbedaan dari penelitian ini ialah, sama-sama meneliti objek naskah drama "Senja dengan Dua Kelelawar" Karya Kirdjomulyo dan perbedaannya terletak pada 
kajian penelitian, penelitian Anis mengkaji tentang Analisis penyimpangan prinsip kerja sama sedangkan penelitian ini meneliti tentang gaya bahasa wujud metaforis dalam naskah drama.

\section{METODE PENELITIAN}

Penelitian ini menggunakan metode deskriptif kualitatif karena merupakan penelitian yang dilakukan dengan mengamati fenomena suatu bahasa pada suatu kurun waktu tertentu dan bersifat deskriptif (Mahsun, 2006:84). Fokus penelitian ini adalah metafora dalam naskah drama Senja dengan Dua kelelawar karya Kirdjomulyo. Secara lebih khusus, penelitian ini fokus untuk mengetahui enis-jenis serta makna metafora dalam naskah drama Senja dengan Dua kelelawar karya Kirdjomulyo teori Parera (2004). Teknik pengumpulan data yang digunakan dalam penelitiaan ini adalah teknik catat, karena data-datanya berupa teks.

Teknik analisis data menurut (Sugiyono, 2014: 247) dapat diklasifikasikan menjadi tiga yaitu reduksi data, penyajian data dan verivication. Reduksi data (data reduction) merupakan cara peneliti untuk merangkum, memilih hal-hal yang pokok, memfokuskan pada hal-hal yang penting, mecari tema dan polanya. Penyajian data (data display) merupakan upaya peneliti untuk menyajikan data sebagai suatu informasi yang memungkinkan untuk mengambil kesimpulan, dengan mendisplay data maka akan mempermudah untuk memahami apa yang terjadi, merencanakan kerja selanjutnya berdasarkan apa yang telah dipahami. Verivication merupakan tahapan terakhir. Pada tahap ini peneliti mencari hubungan kejadian sebab akibat, persamaan atau perbedaan, susunan deskripsi dari hasil observasi, serta hasil dokumentasi yang disusun secara sistematis.

\section{HASIL DAN PEMABAHASAN}

\section{Jenis-Jenis dan Makna Metaforis}

Jenis metafora menurut Parera (2004:24) terdiri dari empat kelompok yaitu: (1) metafora antropormorfik (2) metafora hewan (3) metafora abstrak ke konkret (4) metafora sinestesia.

\section{Metafora Antropomorfik}

(1) Dari arah rumahnya terdengar suara petikan gitar ayahnya yang sudab tua, ayah yang sangat menyayanginya.

Pada kutipan di atas yang temasuk metafora anaforis yaitu petikan gitar ayahnya yang sudah tua. Gitar merupakan menda mati yang dibandingkan seakan-akan menjadi tua seperti manusia. Dari kutipan tersebut mengandung makna bahwa gitar milik ayahnya Ismiyanto sudah lama.

\section{(2) Dari arah rumah suara gitar itu mendekat dan} terus menyanyikan lagu-lagu yang dibafal.

Kutipan di atas merupakan metafora antropomorfik, yang menandakan yaitu rumah suara gitar itu mendekat dan terus menyanyikan lagu-lagu yang dihafal. Gitar merupakan benda mati yang diumpamakan mendekat dan menyanyi seperti manusia. Makna dari kutipan di atas ialah ada suara gitar yang terdengar dekat dari rumah. Gitar itu dimainkan oleh Marsudi. 


\section{(3) (Tertawa). Tiap lagu banya bisa Bapak nyanyikan kepalanya melulu.}

Kutipan di atas termasuk metafora antropomorfik yang menandkan yaitu tawa yang enak. Kepada merupakan bagian tubuh manusia namun diumpamakan sebagai nyanyikan kepala. Makna dari kutipan di atas yaitu kepala dapat diartikan sebagai bagian yang utama atau pokok. Ismiyati mengatakan bahwa bapaknya hanya menyanyikan lirik dari lagu tersebut yang penting-penting saja atau yang dihafal.

(4) Ini, lagu jaub di mata (Tampak betul-betul tahu). Mungkin juga sekarang saat-saat kesepian begini. (Ia mengulang sekali lagi bait pertama dan kedua).

Kutipan diatas termasuk metafora antropomorfik yang menandakan yaitu lagu jauh di mata. Pada kalimat tersebut mata dibandingkan dengan lagu yang jauh dari mata. Makna dari kalimat tersebut yaitu Marsudi mengatakan bahwa lagu yang dinyanyikan jauh dari pandangan.

(5) Bukan begitu, Mas. Saya menirukan itu karena tergetar mendengar nyanyian itu, sehingga dengan tidak sengaja, suara itu lari dari kerongkongan, mengikuti suara yang bening (Keduanya tertawa).

Kutipan di atas termasuk metafora antropomorfik sebagai penanda yaitu pada kalimat, suara itu lari dari kerongkongan, mengikuti suara yang bening. Lari merupakan pekerjaan manusia, pada kutipan tersebut suara sekan-akan dapat lari dari kerongkongan dan mengikuti suara yang bening. Makna dari kutipan tersebut ialah Tomo mengatakan bahwa ia sedang menirukan suara yang terdengar sangat bagus ditelinganyaia mengumpamakan suara itu lari dari kerongkongannya.

(6) Aku betul-betul dapat membayangkan bagaimana kerasnya penyakit kesepian itu

Pada kutipan di atas yang menandakan metafora a antropomorfik yaitu kerasnya penyakit kesepian itu. Penyakit dumpamakan mengalami kesepian. Makna dari kutipan di atas yaitu bahwa kesepian merupakan keadaan yang dialami seseorang yang sangat menganggu keadaanya. Marsudi menganggap Ismiyati mengalami kesepian yang teramat besar.

(7) Tomo : (Agak reda dari kegelisahannya) oh ... (Menarik napas panjang). Saya kira perampokan lagi. Bunub diri mestinya. Zaman kalo edan. Pak Sudi tidak kesana? (Sambilberlalu)

Kutipan di atas yang menandakan metafora antropomorfik ialah Zaman kalo edan. Zaman merupakan waktu atau masa. Edan kata lain dari gila yang memiliki makna tidak waras, tidak semestinya, tidak masuk akal. Zaman edan dapat dimaknai bahwa masa atau zaman yang tidak masuk akal. Tomo mengungkapkan bahwa zaman kalo sudah edan bermakna bahwa ada seseorang yang bunuh diri di rel kereta dan mengagap hal itu gila.

(8) Tetapi peristiwa ini tetap suatu noda 
Kutipan di atas yang menandakan metafora antropomorfik ialah peristiwa ini tetap suatu noda. Peristiwa dianggap noda artinya peristiwa bunuh diri itu dianggap sebagai aib yang tidak seharusnya dilakukan. Menganggap Ismiyati yang melakukan pembunuhan terhadap Mursiwi dan apabila hal itu terbongkar termasuk aib bagi dirinya

(9) Artinya bir ini nyaman

Jenis metafora antropomorfik dalam kutipan diatas yaitu bir ini. Bir merupakan minuman beralkohol sedangkan nyaman ialah segar, sedap sejuk enak. Bir diumpamakan nyaman maksudnya. Bir yang dibawa siswo rasanya enak dan menyenangan

\section{Metafora Hewan}

(10) Dua kelelawar tampak berkejaran, berputar mengelilingi tempat yang suram, mengesankan kengerian dan keseraman

Kutipan di atas termasuk kategori metafora hewan yang menandakan yaitu Dua kelelawar tampak berkejaran. Dua kelelawar digambarkan sedang berkejaran di tempat yang suram dan menakutkan.

(11) Malam semakin sepi mengigit, terdengar petikan gitar dari jauh. Suara gitar mengerakan sehingga terdesak oleh perasaaan asing. Asing sekali dania melempar sebuah batu yang lebih besar, mengenai rel. Ia kembali duduk, tidak tahu bahwa seseorang (Mardikun, kepala stasiun) yang berdiri di dekatnya.

Kutipan di atas yang menandakan metfora hewan yaitu Malam semakin sepi mengigit. Aktivitas mengigit biasanya dilakukan oleh hewan yang memiliki taring. Namun, dalam kutipan tersebut mengigit diumpamakan ialah sepi. Sepi mengigit dapat dimaknai segabai suasana sepi yang menakutkan, tidak ada seseorag atu siapapun.

(12) Aku menjadi perempuan jalang karena mencintai dia?

Kutipan di atas yang menandakan metafora hewan yaitu perempuan jalang. Jalang ialah tidak dipelihara orang (tentang binang) atau bisa diartikn liar. Kata liar biasanya diperuntukkan binatang yang tidak dipelihara. Pada kutipan di atas perempuan diumpaman liar. Perempuan jalang dapat dimaknai sebagai perempuan yang nakal.

\section{Metafora Abstrak Ke Konkret}

(13) Kau ini betul-betul tidak mengerti kesenian. (Keduanya tertawa). Orang baru mencurahkan jiwa raganya pada irama yang begini menghanyutkan, ditirukan seenaknya (Menirukan suara yang parau itu).

Kutipan di atas yang menandakan wujud metafora abrak ke konkret yaitu mencurabkan jiwa raganya pada irama yang begini menghanyutkan. Mencurahkan jiwa merupakan 
metafora abstrak ke konkret karena mencurahkan jiwa tidak ada wujud konkretnya. kalimat tersebut dapat dimaknai bahwa Marsudi sedang menuangkan jiwa atau rohnya pada alunan lagu yang mengalir.

(14) Ismiyati tersenyum getir, tersinggung.

Kutipan diatas termasuk metafora abrak ke konkret. Tersenyum berarti memberikan senyuman. Getir dapat diartikan sebagai susah dan sengsara. Kata getir merupakan wujud abstrak yang diumpamakan menjadi bentuk konkret. Tersenyum getir bermetafora dengan ungkapan senyuman kesengsaraan atau kesdihan.

(15) Layar turun sebentar, ketika layar terangkat senja berikutnya membayang di arah barat

Kutipan di atas termasuk metafora abstrak ke konkret sebagai penanda yaitu senja berikutnya membayang di arah barat. Senja sendiri berarti waktu setengah gelap sesudah matahari terbenam. Senja merupakan wujud abstrak yang dikonkretkan membayang. Kutipan di atas dapat dimaknai dengan pada waktu senja terlihat dari arah barat.

(16) Tiap hari kau berdiri disitu menunggu Suwarto. Itu akan merusak kesehatanmu. Sudah terang Suwarto gelisah memikirkan istrinya. Gelisah mencari pembunuh istrinya. Sudah semestinya ia belum memikirkan kau. (Diam, menghisap rokoknya sambil menunggu reaksi). Semestinya jika ia tidak memperdulikan kau. Apa kata orang lain tentang kau, bila kau begitu gelap bati. Mengejar-ngejar seseorang yang baru saja ditinggal mati istrinya. Apa kata orang tentang aku, seorang tua yang tidak bisa memberi nasihat anaknya.

Kutipan di atas termasuk metafora abstrak ke konkret yang menandakan yaitu gelap hati. Hati merupakan wujud asbtrak yang seakan-akan memiliki wujud nyata. Dalam kutipan di atas hati dimaknai dengan sifat atau batin manusia yang diumpamakan menjadi gelap. Gelap diartikan sebagai tidak dapat melihat keadaan. Gelap hati dimaknai dengan hati yang sudah terlalu dalam mencintai seseorang hingga ia mampu melakukan apapun demi mendapatkan seseorang yang ia cintai.

$$
\begin{aligned}
& \text { (17) Ia akan merendam bidup kita pada panas } \\
& \text { belerang, yang sewaktu-waktu akan } \\
& \text { membakar kesadaran kita dan terjadilah } \\
& \text { sesuatu di luar kekuasaan kita. Saya tidak } \\
& \text { menyesali melakukan itu, dan tidak } \\
& \text { menyesal menyerahkan diri. (Pergi). }
\end{aligned}
$$

Kutipan di atas termasuk metafora abstrak ke konkret sebagai penanda yaitu merendam bidup kita pada panas belerang. Merendam hidup adalah wujud abstrak yang dikonkretkan merendam pada panas belerang. Merendam dapat diartikan sebagai menaruh di dalam air. Hidup dapat diartikan sebagai masih terus ada dan sebagaimana mestinya. 
Sedangkan panas dapat diartikan sebagai suhu dan belerang adalah benda yang bukan logam yang berwarna kuning muda. Kutipan di atas dapat dimaknai bahwa Sulaiman mengakui kebenaran bahwa dirinya yang mendorong Mursiwi ke rel kereta api, lantaran Mursiwi bukan orang yang baik, dirinya bisa saja menyakiti hati seseorang sampai merendam pada belerang yang panas.

(18) Ia akan terbuka hatinya pada suatu ketika.

Kutipan di atas termasuk matafora abstrak ke konkret penandanya yaitu terbuka hatinya. Terbuka hatinya merupakan wujud abstrak yang dijadikan konkret, makna dari kutipan tersebut ialah membuka hati dapat diartika seagai memberi kesempatan lagi atau tidak menutup hati kepada siapapun.

(19) Hampir-hampir aku tak anggup menerima cintamu ini. Cintamu begitu besar, jujur dan berani. Cintaku ... Begitu asing, berdarah dan tidak sekuat perasaanmu

Kutipan di atas termasuk metafora abstrak ke konkret. Yang menandakan yaitu Cintamu begitu besar, jujur dan berani. Cintaku ... Begitu asing, berdarah dan tidak sekuat perasaanmu. Cinta merupakan wujud abstrak yang dikonkretkan seakan-akan berwujud nyata. Kutipan diatas dapat dimaknai bahwa cinta itu besar, jujur, dan berani. Cinta asing dan berdarah. Cinta berarti suka sekali atau sayang. Kutipan di atas dapat dimaknai bahwa perasaan cinta Ismiyati sangat besar, jujur dan berani sedangkan perasaan Suwarto masih asing dan tidak sebesar cinta Ismiyanti. Lantaran Ismiyati berani berkorban mengakui yang bukan kesalahannya demi mendapatkan perhatian dari Suwarto.

\section{Metafora Sinestesia}

(20) Dari arah kiri terdengar dua orang bercakap-cakap diseling tawa yang enak, menuju tempat itu

Kutipan di atas termasuk metafora sinestesia, sebagai penanda yaitu tawa yang enak, kata enak biasanya identic dengan indra perngecap atau perasa dalam kalimat tersebut enak diumpamakan sebagai situasi atau keadaan. Makna dari kutipan di atas yaitu ungkapan gembira yang diwujudkan dari tawa yang enak maksudnya tawa yang menyenangkan.

(21) Ya, bukan kau yang membunuh dia, Diam memandang dengan tajam). Seorang pemuda yang membunuhnya.

Kutipan di atas termasuk metafora sinestesia yang menandakan yaitu Diam memandang dengan tajam. Memandang adalah indra penglihatan yang dialihkan seolah-olah pandanganya menjadi buas atau galak.

(22) seorang mengerti sebabnya, tapi begitu yang terjadi padanya. Di balik kecantikannya, pandangan yang menggairabkan, perkataannya yang menghangatkan kehidupan, dan kewanitaannya yang mengguncangkan kepercayaan. Mungkin ia 
pernah sakit hati semacam saya sakit hati

terhadap dia.

Kutipan di atas merupakan metafora sinestesia sebagai penanda yaitu pandangan yang menggairabkan, perkataannya yang menghangatkan kehidupan. Pandangan merupakan indra penglihatan yang dialihkan menjadi indra perasa. Sedangkan perkataan merupakan indra pengecap yang dialihkan menjadi indra perasa. Kutipan di atas dapat dimaknai dengan seseorang yang memiliki kecantikan yang mempesona dapat membangkitkan hawa nafsu, perkataannya dapat menenangkan kehidupan. Dibalik itu tersembunyi perasaan sakit hati yang tidak dapat dilupakan yang kemudianmenjadi dendam.

(23) Tomo : (Pandangan tajam mencari-cari).

Apa yang lain?Aaa...,bakpia (keras, terkejut

lega). Ini makanan yang menarik buat saya.

Terimakasih! katakan begitu Nona Manis.

Kutipan di atas termasuk metafora sinestesia yang menandakan yaitu Nona Manis. Manis merupakan bagian dari indra pengecap atau perasa dialihkan menjadi indra penglihatan. Nona manis dapat dimaknai dengan perempuan yang memiliki wajah elok dan cantik.

\section{SIMPULAN}

Berdasarkan analisis data yang dilakukan terhadap naskah drama Senja dengan Dua Kelelawar karya Kirdjomulyo mengandung empat jenis gaya bahasa metafora menurut teori Parera yang terdiri darimetafora antropomorfik, metafora hewan, metafora abstrak ke konkret, dan metafora sinestesia. Jenis gaya bahasa anaforis yang membandingka pengalaman dengan apa yang terdapat pada tubuh manusia terdapat 9 data, jenis gaya bahasa hewan menggambarkan kondisi metafora dengan unsur binatang tedapat 3 data, jenis gaya bahasa abstrak ke konkret mengalihkan ungkapan-ungkapan yang abstrak ke ungkapan yang lebih konkret, sering pengalihan ungkapan itu masih bersifat transparan terdapat 7 data dan jenis gaya bahasa metafora sinestesia terdapat berdasrkan pengalihan indra, pengalihan dari satu indra ke indra yang lain 4 data.

\section{DAFTAR PUSTAKA}

Anawati, Arnis. 2016. Analisis Penyimpangan Prinsip Kerja Sama dalam Naskah Senja dengan Dua Kelelawar Karya Kirdjomulyo. Skripsi. Universitas Negeri Yogyakarta.

Brata, I Komang Soni Anggarika Suwirna. 2018. Analisis Bentuk dan Fungsi Gaya Bahasa dalam Naskah Drama L'annonce Faite À Marie Karya Paul Claudel. Skripsi. Universitas Negeri Yogyakarta

Dwi Suprabowo dan Gunawan Wiradharma. 2018. "Nasionalisme Utuy Tatang Sontani dalam Naskah Drama Bunga Rumah Makan yang Bertema Roman Picisan: Hermeneutika Sastra". Jurnal Arkhais, Vol 9 (1), 1-11.

Giyoto. 2013. Modul Analisis Semantik Text Book Mahasiswa Program Studi Bahasa. Surakarta: Fataba Press.

Mahsun, M.S. 2006. Metode Penelitian Bahasa: Tahapan Strategi, Metode, dan Tekniknya. Jakarta: PT Raja Grafindo Persada. 
ISSN (Online): 2621-0851

Volume 2, Nomor 1, Mei 2019

Parera. 2004. Teori Semantik. Jakarta: Erlangga

Pateda, Mansoer. 2010. Semantik Leksikal. Jakarta: Rineka Cipta.

Verhaar, JWM. 2008. Asas-asas Linguistik Umum. Yogyakarta: Universitas Gajah Mada Press.

Widyahening, Evy Tri. Kajian Drama Teori dan Implementasi engan Metode Sosiodrama. Surakarta: Cakrawala Media. 